\title{
Detection of Cross-reactive Anti-DNA Antibody Idiotypes on Renal Tissue-bound Immunoglobulins from Lupus Patients
}

\author{
David A. Isenberg and Christopher Collins \\ Departments of Rheumatology and Morbid Anatomy, University College Hospital London W.C.1. England
}

\begin{abstract}
Cross-reactive anti-DNA antibody idiotypes have been identified on tissue-bound immunoglobulins in a study of renal biopsies from 26 systemic lupus erythematosus (SLE) patients. 12 (46\%) biopsies were shown to have one or both the idiotypes tested for by anti-idiotypic reagents. The idiotypes were identified in the glomerular basement membrane, the mesangial cell cytoplasm, and in focal tuft proliferations. In contrast, in none of 24 immunoglobulin-positive disease control biopsies could either idiotype be demonstrated. Blocking studies in two patients indicated that the idiotypes were on anti-DNA antibodies. These findings indicate that some tissue-bound autoantibodies are derived from related families of high-frequency germ line genes that are expressed in SLE patients. The potential role of anti-idiotypic therapy in SLE is discussed.
\end{abstract}

\section{Introduction}

Autoantibodies in the serum of patients with systemic lupus erythematosus (SLE) ${ }^{1}$ can bind to a wide variety of antigens, including nucleic acids, nucleoproteins, cell membranes, and phospholipids (1). Some of these autoantibodies, notably those thought to be directed against single- and double-stranded DNA, have been shown to contribute to the formation of lesions in the kidney (2) and skin (3) of patients with SLE.

We have studied renal tissue-bound lupus autoantibodies by a method that is independent of their DNA binding properties. The technique employed depends upon the detection of anti-DNA antibody idiotypes. An idiotype is a serologically defined marker of the variable region of an antibody (4). Each antibody molecule contains in this region unique amino acid sequences that contribute both to its antigen binding domain as well as all or part of the immunogenic determinant that constitute its idiotype. The sharing of idiotypes by autoantibodies found in different patients suggests that they are the products of germ line genes that are dispersed throughout the population (5).

Similarities or differences in idiotypic markers are detectable by means of anti-idiotypic antibodies. These have been prepared

Address correspondence to Dr. Isenberg.

Received for publication 27 August 1984 and in revised form 7 February 1985.

1. Abbreviations used in this paper: anti-32/15-M, monoclonal antiidiotype; anti 16/6-R, rabbit anti-idiotype; anti-16/R-R, anti-idiotypic sera; NZB/NZW, New Zealand black mice/New Zealand white mice; SLE, systemic lupus erythematosus.

J. Clin. Invest.

(C) The American Society for Clinical Investigation, Inc. $0021-9738 / 85 / 07 / 0287 / 08 \quad \$ 1.00$

Volume 76, July 1985, 287-294 by immunizing animals with polyclonal (6) or monoclonal (7) anti-DNA antibodies obtained respectively from lupus patients' serum or human-human hybridomas. Substantial sharing of certain anti-DNA antibody idiotypes has been demonstrated amongst monoclonal anti-DNA antibodies (7) and serum antiDNA antibodies (8) from SLE patients. We have attempted to extend these observations by investigating whether immunoglobulins found in the renal biopsies of SLE patients share common idiotypes.

\section{Methods}

The renal biopsies from 26 SLE patients were studied. 25 patients met four or more of the revised American Rheumatism Association's

Table I. Clinical and Serological Features of the SLE Patients at the Time of Their Renal Biopsies

\begin{tabular}{|c|c|c|c|c|c|}
\hline Patient & Clinical features & ANA & dsDNA & C3 & CIC \\
\hline 1 & $\mathrm{R}, \mathrm{A}, \mathrm{P}, \mathrm{D}, \mathrm{T}$ & $1: 2,560$ & 44 & 0.33 & 383 \\
\hline 2 & $\mathbf{R}, \mathbf{A}$ & - & - & 1.4 & 一 \\
\hline 3 & $\mathrm{R}, \mathrm{A}$ & $1: 640$ & 62 & 1.26 & 90 \\
\hline 4 & $\dot{R}, A, P, D$ & $1: 160$ & 460 & 0.69 & 106 \\
\hline 5 & $\mathrm{R}, \mathrm{A}, \mathrm{P}, \mathrm{D}$ & $1: 320$ & - & - & - \\
\hline 6 & $\mathrm{R}, \mathrm{D}$ & $1: 1,280$ & 15 & - & - \\
\hline 7 & $\mathbf{R}$ & $1: 320$ & 0 & - & - \\
\hline 8 & $\mathbf{R}$ & $1: 1,280$ & 45 & 3.0 & 49 \\
\hline 9 & $\mathrm{R}, \mathrm{A}, \mathrm{P}, \mathrm{D}, \mathrm{T}$ & $1: 160$ & 35 & 0.25 & 34 \\
\hline 10 & $\mathrm{R}, \mathrm{A}, \mathrm{P}, \mathrm{D}$ & $1: 320$ & 1,312 & 0.58 & 794 \\
\hline 11 & $\mathrm{R}, \mathrm{A}$ & $1: 80$ & 86 & - & - \\
\hline 12 & $\mathrm{R}, \mathrm{P}, \mathrm{D}$ & $1: 2,560$ & 45 & 0.84 & 325 \\
\hline 13 & $\mathrm{~A}, \mathrm{P}$ & $1: 320$ & - & 1.38 & 491 \\
\hline 14 & $\mathrm{R}, \mathrm{A}, \mathrm{P}, \mathrm{D}$ & $1: 320$ & 320 & 0.78 & 92 \\
\hline 15 & $\mathrm{R}, \mathrm{A}, \mathrm{C}, \mathrm{P}, \mathrm{D}$ & $1: 1,280$ & 160 & 0.99 & 51 \\
\hline 16 & $\mathrm{R}, \mathrm{A}, \mathrm{P}, \mathrm{D}$ & $1: 640$ & 230 & 1.2 & 420 \\
\hline 17 & $\mathrm{R}, \mathrm{A}, \mathrm{D}$ & $1: 640$ & 6 & 0.97 & 0 \\
\hline 18 & A, P, D & $1: 5,120$ & 34 & 0.45 & 266 \\
\hline 19 & $\mathrm{R}, \mathrm{A}, \mathrm{P}, \mathrm{T}$ & $1: 640$ & 31 & 0.81 & 60 \\
\hline 20 & $\mathrm{R}, \mathrm{A}, \mathrm{C}, \mathrm{P}, \mathrm{D}, \mathrm{T}$ & $1: 2,560$ & 1,081 & 1.1 & 80 \\
\hline 21 & $\mathrm{R}, \mathrm{A}, \mathrm{D}$ & $1: 320$ & 135 & 0.25 & 43 \\
\hline 22 & $\mathbf{R}, \mathrm{A}, \mathrm{C}, \mathrm{P}$ & $1: 320$ & 15 & 0.69 & 117 \\
\hline 23 & A, P, D & $1: 320$ & 12 & 1.39 & 139 \\
\hline 24 & $A, C, P, D$ & $1: 320$ & 56 & 0.80 & 363 \\
\hline 25 & $\mathrm{~A}, \mathrm{C}, \mathrm{P}$ & $1: 320$ & 22 & 1.47 & 29 \\
\hline 26 & R, P, D & $1: 320$ & 171 & 0.36 & 239 \\
\hline
\end{tabular}

R, renal; A, arthralgia; P, pulmonary/pericardial; D, dermatological; $\mathrm{T}$, thrombocytopenia; C, cerebral. These major features are classified according to the study by Morrow et al. (11). The upper limit of normal for the dsDNA antibody level (Amersham International) is 25 $\mathrm{U} / \mathrm{ml}$; the normal range for serum C3 is $0.84-1.65 \mathrm{~g} /$ liter, and the upper limit of normal for circulating immune complexes (CIC) is 100 ng ml-1 IgG. 
Table II. Immunoglobulin-positive Disease Control

\begin{tabular}{ll}
\hline Control diseases studied & Number \\
\hline Idiopathic membranous glomerulonephritis & 4 \\
Mesangial proliferative glomerulonephritis & 3 \\
Focal glomerulonephritis & 2 \\
IgA nephropathy & 3 \\
Diabetic nephropathy & 3 \\
Henoch-Schoenlein nephritis & 1 \\
Polyarteritis nodosa & 2 \\
Focal glomerulosclerosis/hyalinosis & 3 \\
Glomerulonephritis associated with systemic disease & 3 \\
$\quad$ (Paraproteinaemia 1 & \\
Sarcoidosis 1 & \\
$\quad$ Mesothelioma 1) &
\end{tabular}

criteria (9) for the classification of the disease. One patient had arthralgia, abdominal pain, proteinuria, and a renal biopsy consistent with SLE. The patient's return to the Sudan after biopsy prevented further follow-up.

Two patients were biopsied twice and one patient three times. The clinical details of all of these patients and the results of their serum C3 measured by radial immunodiffusion (10), circulating immune complexes (11), anti-nuclear antibody, and anti-dsDNA antibodies (Amersham kit, Amersham International, Buckinghamshire, England) at the time of biopsy are shown in Table I.

As controls, the renal biopsies from 24 other patients were examined (Table II). Each of these biopsies had immunoglobulin deposition in the kidney, but none of the patients had clinical evidence of SLE at the time of biopsy. The case notes of 22 of these patients who were examined, and during a mean follow-up period of 15 mo (range 144) none subsequently developed SLE. The remaining patients returned to their countries of origin and were not followed up.

Anti-idiotypic antibodies. A human-human hybridoma technique (12) was used to produce two human monoclonal IgM anti-DNA antibodies, which were designated $16 / 6$ and $32 / 15$.
One anti-idiotypic sera (anti-16/R-R) was prepared by immunization of a rabbit as previously described (7). The serum was rendered idiotype specific by extensive absorption on a human IgG/IgM Sepharose column. The production of the monoclonal mouse anti-idiotypic sera (anti-32/15-M) has also been described (7). Both the antigen binding characteristics of the two monoclonal antibodies (containing the idiotypes) and the binding characteristics of the two anti-idiotypes have been reported elsewhere $(7,12)$. It may be reiterated that neither of the anti-idiotype antibodies reacted with IgM immunoglobulins from over 20 normal donors, IgM immunoglobulins from patients with myelomas or Walderström's macroglobulinaemia, or a variety of IgG or IgA immunoglobulins or light chains. Competition assays with various polynucleotides indicated that the anti-idiotypes react with or close to the antigen binding domains of their corresponding idiotypes. As previously described (7), neither of the anti-idiotypes bound to ss or dsDNA or synthetic polynucleotides.

Detection of idiotype in renal biopsy material. Paraffin sections from each biopsy fixed uniformly in unbuffered formol saline were treated with $0.1 \%$ trypsin in $0.1 \%$ calcium chloride (adjusted to $\mathrm{pH}$ 7.8) for between 20 and $30 \mathrm{~min}$ at $37^{\circ} \mathrm{C}$ and then washed in running water for $5 \mathrm{~min}$. After washing for $20 \mathrm{~min}$ in Tris-buffered saline, the sections were incubated for $1 \mathrm{~h}$ with either the monoclonal antiidiotype (anti-32/15-M) or with the rabbit anti-idiotype (anti-16/6R). Sections incubated with anti-32/15-M were washed $(3 \times 10 \mathrm{~min}$ in Tris-buffered saline) and incubated with peroxidase-conjugated rabbit anti-mouse Ig (Dakopatts, Surrey, United Kingdom) that was diluted 1:100 in Tris-buffered saline for $30 \mathrm{~min}$. Those treated with anti-16/6-R were washed in Tris-buffered saline three times for 10 min; incubated with swine anti-rabbit Ig diluted 1:100 for $30 \mathrm{~min}$ (Dakopatts); washed in Tris-buffered saline three times for $10 \mathrm{~min}$ and incubated with peroxidase/rabbit antiperoxidase at a dilution of 1:200. After further washing in Tris-buffered saline for $3 \times 10 \mathrm{~min}$, a solution of diaminobenzidine $(0.5 \mathrm{mg} / \mathrm{ml})$ and hydrogen peroxide $(0.01 \%)$ was applied for $10 \mathrm{~min}$ and the sections were washed in running water for 5 min, counterstained with haematoxylin, and mounted. All sections were controlled by simultaneous processing of sections to which the primary antisera had not been applied. In no case was positive staining seen.

As a further control, pooled normal rabbit serum and pooled normal mouse serum processed in an identical manner to the rabbit

Table IIIA. Light Microscopy, Immunohistochemistry, Electron Microscopy, and Idiotype Findings on the Idiotype-positive SLE Patients

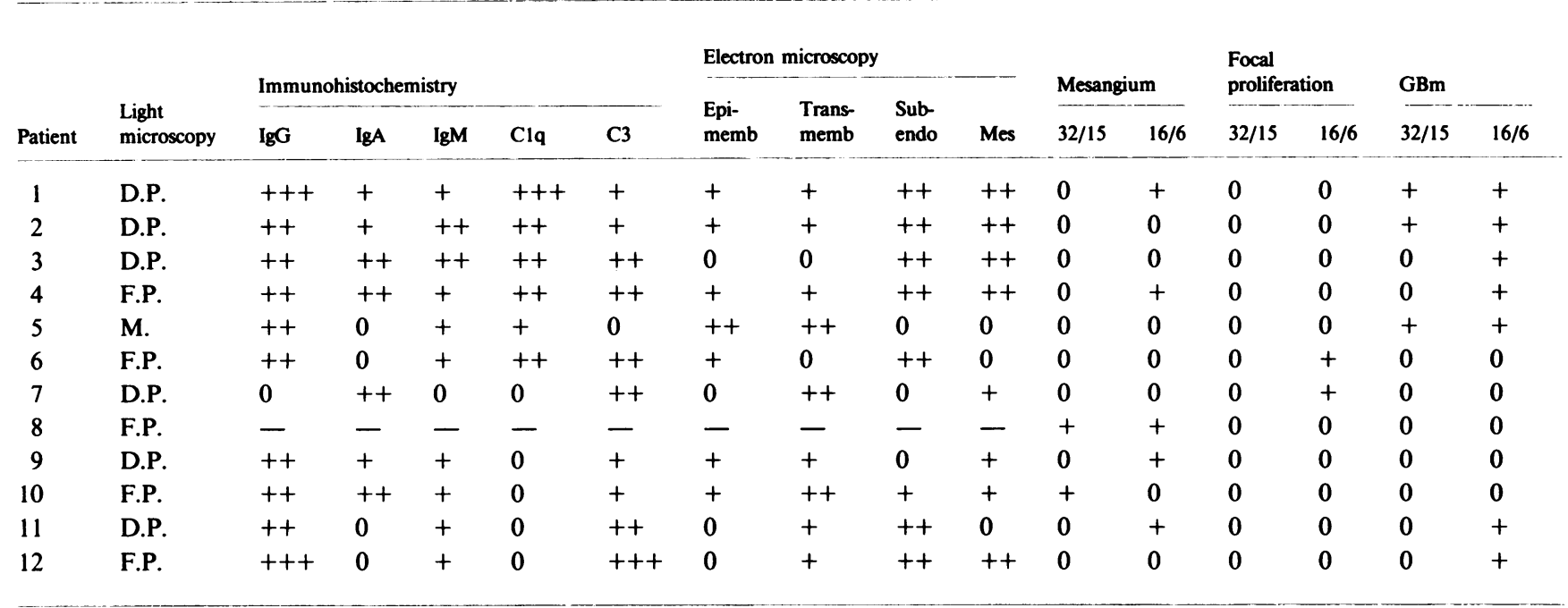

Epimemb, epimembranous; Transmemb, transmembranous; Subendo, subendothelial; Mes, mesangial; Focal prolif, tuft focal proliferation; GBm, glomerular basement membrane; D.P., diffuse proliferative; F.P., focal proliferative; M., membranous. The scoring system for the immunohistochemistry and idiotype detection is on a semi-quantitative zero to +++ scale. 
Table IIIB. Light Microscopy, Immunohistochemistry, and Electron Microscopy on the Idiotype-negative SLE Patients

\begin{tabular}{|c|c|c|c|c|c|c|c|c|c|c|}
\hline \multirow[b]{3}{*}{ Patient } & \multirow{3}{*}{$\begin{array}{l}\text { Light } \\
\text { microscopy }\end{array}$} & \multirow{2}{*}{\multicolumn{5}{|c|}{ Immunohistochemistry }} & \multicolumn{4}{|c|}{ Electron microscopy } \\
\hline & & & & & & & \multirow{2}{*}{$\begin{array}{l}\text { Epi- } \\
\text { memb }\end{array}$} & \multirow{2}{*}{$\begin{array}{l}\text { Trans- } \\
\text { memb }\end{array}$} & \multirow{2}{*}{$\begin{array}{l}\text { Sub- } \\
\text { endo }\end{array}$} & \multirow[b]{2}{*}{ Mes } \\
\hline & & IgG & IgA & IgM & $\mathrm{Clq}$ & $\mathrm{C} 3$ & & & & \\
\hline 13 & Mes. P. & ++ & 0 & ++ & 0 & + & + & + & + & + \\
\hline 14 & D.P. & + & ++ & + & ++ & + & 0 & 0 & ++ & + \\
\hline 15 & D.P. & ++ & 0 & 0 & 0 & ++ & 0 & + & ++ & 0 \\
\hline 16 & F.P. & + & + & + & 0 & + & 0 & + & + & 0 \\
\hline 17 & M. & ++ & 0 & + & + & ++ & + & ++ & 0 & 0 \\
\hline 18 & F.P. & +++ & ++ & +++ & 0 & + & 0 & ++ & + & 0 \\
\hline 19 & D.P. & ++ & + & +++ & ++ & ++ & - & - & - & - \\
\hline 20 & D.P. & +++ & +++ & + & +++ & +++ & 0 & + & ++ & + \\
\hline 21 & D.P. & +++ & +++ & +++ & +++ & +++ & + & + & ++ & ++ \\
\hline 22 & M. & ++ & 0 & 0 & 0 & ++ & + & + & 0 & 0 \\
\hline 23 & M. & 0 & ++ & + & +++ & + & ++ & ++ & ++ & ++ \\
\hline 24 & F.P. & ++ & 0 & 0 & 0 & 0 & + & ++ & 0 & 0 \\
\hline 25 & M. & +++ & 0 & ++ & + & 0 & ++ & ++ & 0 & ++ \\
\hline 26 & M. \& P. & 0 & ++ & + & +++ & + & + & + & + & ++ \\
\hline
\end{tabular}

M \& P, membranous and proliferative; Mes. P, mesangial proliferation. The scoring system for the immunohistochemistry is on a semi-quantitative zero to +++ scale.

and mouse anti-16/R-R, respectively, were used to stain representative renal biopsies sections. Thus, four each of the idiotype positive and idiotype negative biopsies were tested. The control rabbit sera was diluted to 1:100 in phosphate-buffered saline (PBS) and the control mouse sera to 1:10 in PBS to parallel the respective anti-idiotypic antisera. All the results were read by a pathologist (Dr. Collins), who was unaware of the clinical status of the patients.

Blocking experiments. In addition, from two biopsies which were found to be positive when stained with anti-16/6-R, sufficient material was available to carry out blocking studies. Biopsies were preincubated, after trypsinization with 2.5 or $25 \mu \mathrm{g}$ of ssDNA and dsDNA diluted in PBS for $1 \mathrm{~h}$ at $37^{\circ} \mathrm{C}$, then $18 \mathrm{~h}$ at $4^{\circ} \mathrm{C}$. Anti-16/6-R (1:100) was then added, and the usual peroxidase procedure (see above) was followed. As a control, one section was preincubated with PBS alone. For these experiments, whose results were read blind, the biopsies were scored on a zero to +++ semi-quantitative scale according to the degree of positive peroxidase staining.

Staining with an irrelevant mouse monoclonal antibody. As a further precaution, sections from patient 1 , whose biopsy was found to be positive when stained with anti-32/15-M, were also stained with a mouse monoclonal antibody (TAL-IB5) that has specificity for HLADr region $\alpha$-chains. The usual peroxidase procedure (see above) was followed. This monoclonal was a gift of the Imperial Cancer Research Fund (Lincolns Inn, London).

Detection of idiotype in the serum of the lupus patients. Because this was a retrospective study, we did not have access to appropriate serum samples in all the patients. However, samples from 10 SLE patients taken within $1 \mathrm{wk}$ of the renal biopsy were studied. Using anti-16/6-R and anti-32/15-M, the $16 / 6$ and 32/15 idiotypes were detected in the serum by a previously described method (8).

\section{Results}

In 12 of the 26 SLE patients tested (46\%), the $16 / 6$ and/or $32 / 15$ idiotypes were detected in renal biopsy tissue. The idiotype-positive patients are those numbered 1-12 in Table I. The results of their routine light histology, electron microscopy, and immunofluorescence microscopy, as well as the details of their idiotype deposition are shown in Table III A. In contrast, in the renal biopsies of 14 SLE patients (numbers

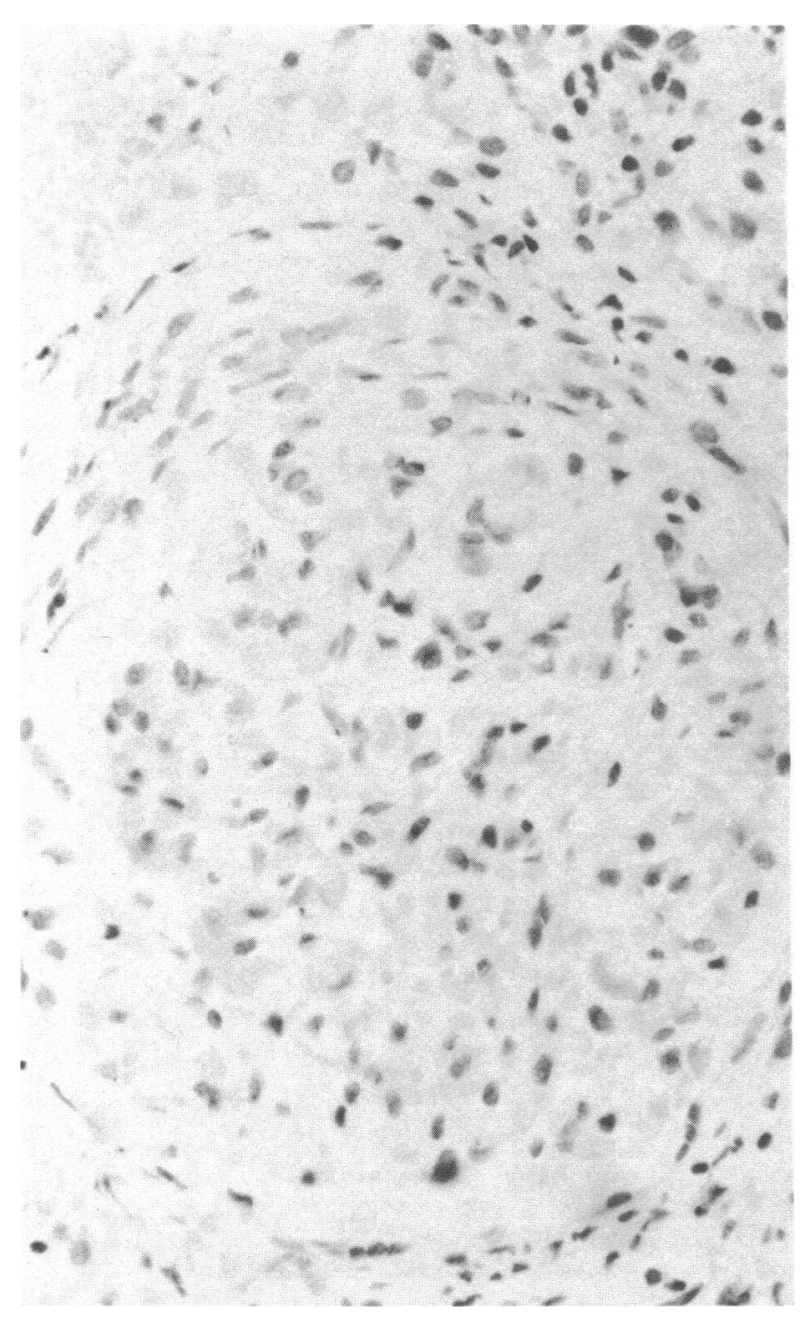

Figure 1. Patient U. Membranoproliferative glomerulonephritis. Section shows no evidence of staining with anti-idiotype anti-sera (anti16/6). (Haematoxylin $\times 260$.) 
13-26, Table I), neither the $16 / 6$ or $32 / 15$ idiotypes were detected. The results of the light histology, electron microscopy, and immunofluorescence microscopy of these idiotype-negative patients are shown in Table III B.

In the renal biopsies of four patients, both the $16 / 6$ and $32 / 15$ idiotypes were found. Seven patients had only the $16 / 6$ idiotype detected in their biopsies, and in one patient $32 / 15$ alone was detected. The 16/6-R and 32/15-M idiotypes were detected in three locations designated, glomerular basement membrane, focal tuft proliferation, and within the mesangium (see Figs. 1-5). Seven patients and three patients were 16/6positive and 32/15-positive, respectively, in the glomerular basement membrane. Similarly, five and two patients were 16/6- and 32/15-positive for staining within the mesangium, and two patients had $16 / 6$ idiotype detectable in a focal tuft proliferation (none were positive in this location for 32/15).

There were no statistically significant correlations between the light microscopic findings, immunohistochemistry, or electron microscopy, and the possession (or pattern) of the crossreacting idiotypes. Neither were there any obvious differences in the biopsies of those lupus patients in whom the crossreactive idiotypes could or could not be demonstrated.

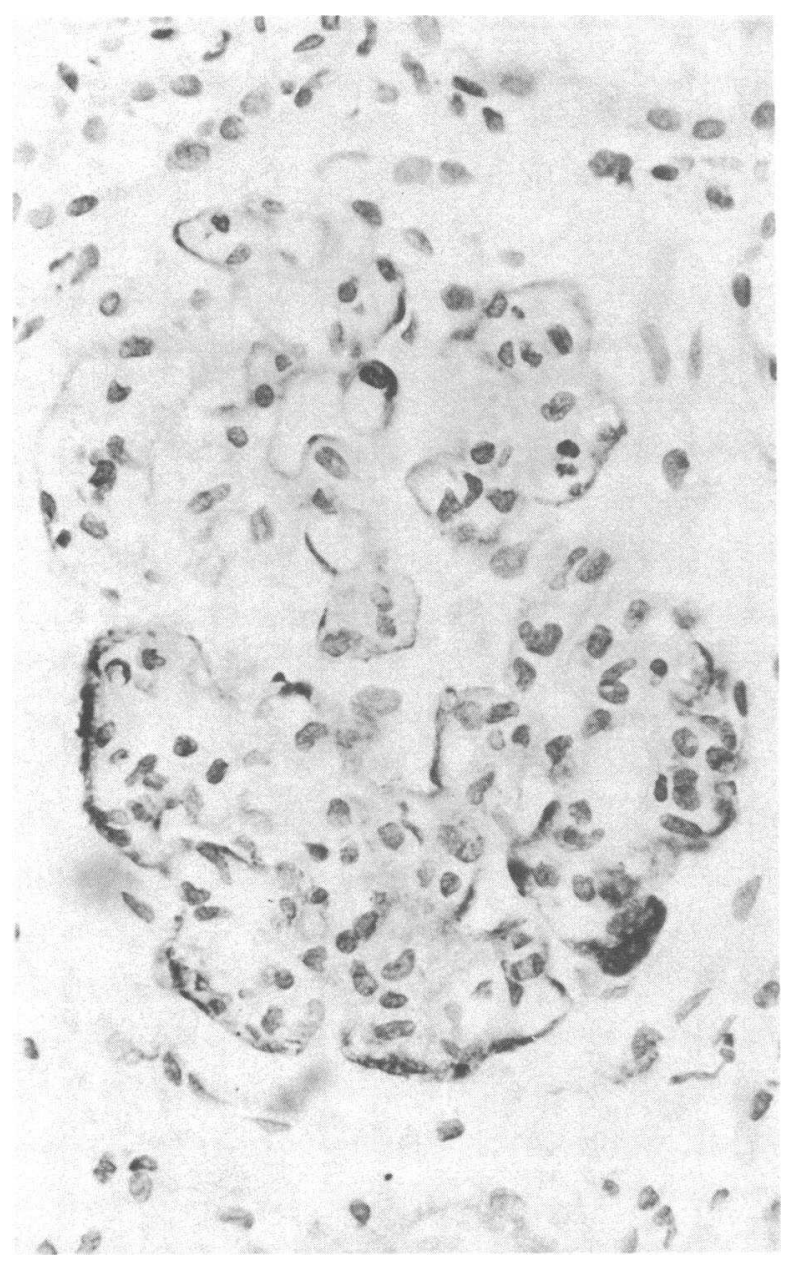

Figure 2. SLE patient 2. Diffuse proliferative lupus glomerulonephritis. Staining with anti-idiotype anti-sera (anti-32/15) shows glomerular basement membrane staining with characteristic lobular outline pattern. $\times 580$.

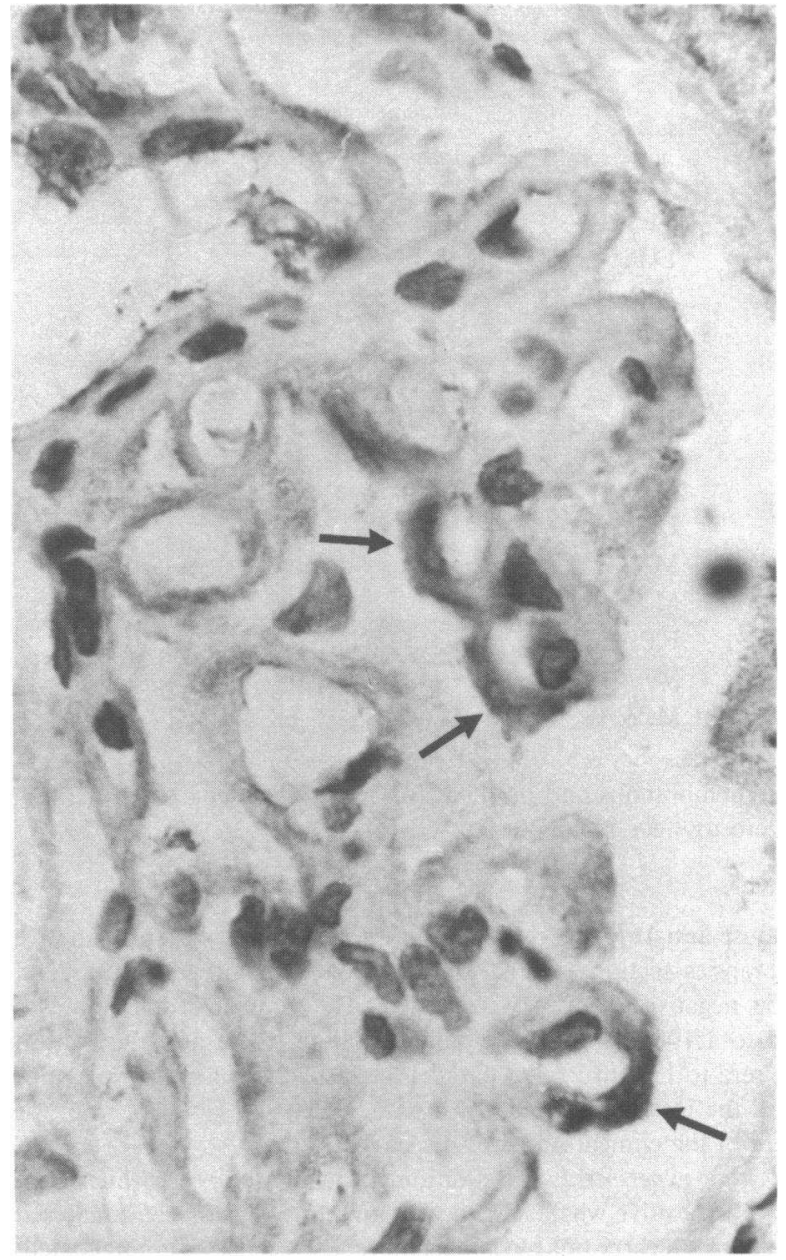

Figure 3. SLE patient 5. Membranous lupus glomerulonephritis. Staining with anti-idiotype anti-sera (anti-16/6) shows coarsely granular staining of thickened glomerular basement membrane (arrows). $\times 1,280$.

The results of the light histology, electron microscopy, and immunofluorescence of the control groups are shown in Table IV. Neither of the idiotypes was detected in any of the control biopsies. No binding was observed using the normal rabbit or normal mouse serum on the representative sections from the idiotype-positive or negative biopsies.

Lupus patient 3 has had three renal biopsies in all. The $16 / 6$ idiotype was detected in the glomerular basement membrane on each occasion. Histologically, her biopsy findings changed from a focal glomerulonephritis (on the first two biopsies, not shown in Table III A) to a diffuse proliferative glomerulonephritis (Table III A). Lupus patients' 7 and 22 have each had two biopsies and both were idiotype-negative on each occasion. In two $16 / 6$ idiotype-positive biopsies, preincubation with either ssDNA or dsDNA almost completely blocked the binding of $R \alpha 16 / 6$ (Table V). No binding of mouse monoclonal antibody (TAL-IB5) in the glomerular basement membrane, mesangium, or tuft proliferation was seen.

Measurement of the serum 16/6 levels (Table VI) showed that four out of five patients in whose biopsies the $16 / 6$ idiotype was detected had raised serum levels. In contrast, 


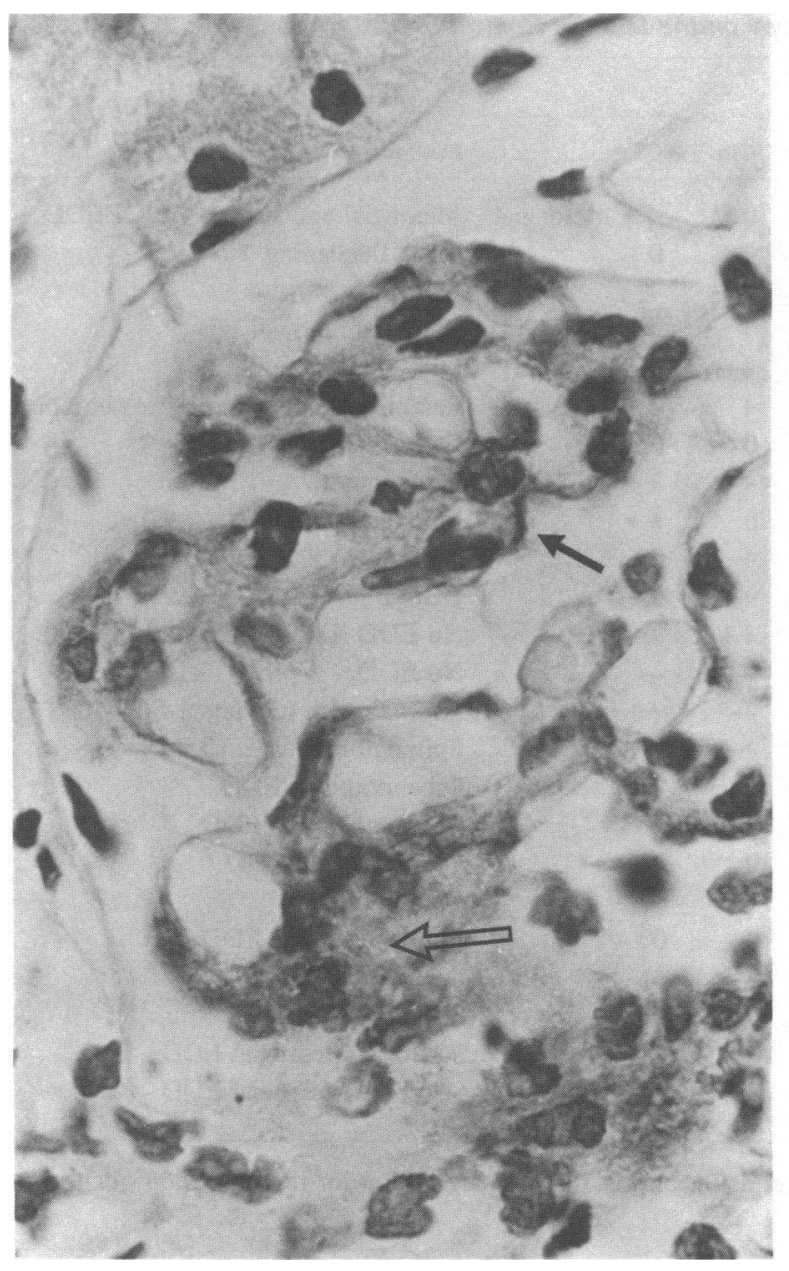

Figure 4. SLE patient 10. Focal proliferative lupus glomerulonephritis. Staining with anti-idiotype anti-sera (anti-32/15) shows finely granular mesangial deposit (open arrows) and glomerular basement membrane staining (solid arrow). $\times 960$.

only one of five patients with 16/6-negative biopsies had elevated serum levels. With the $32 / 15$ idiotype of two patients with positive biopsies, only one (patient 1) had a raised serum level. In addition, two patients (patients 9 and 23) with no $32 / 15$ idiotype detectable in their biopsies had elevated serum levels.

\section{Discussion}

The production of antibodies with shared idiotypes appears to be a general property of the immune system. Thus, idiotypic sharing has been found among antibodies raised in goats to human hemoglobins (13), and human antibodies to hepatitis B surface antigen (14). Similarly, autoantibodies to rheumatoid factors (15), anti-acetylcholine receptor (16) antibodies, antithyroglobulin antibodies (17), and DNA antibodies (7) have all been shown to share idiotypic determinants. These observations indicate restrictions in the repertoire of variable region immunoglobulin genes, and imply that major cross-reactive idiotypic families are the products of common germ line genes dispersed throughout the population rather than the result of somatic mutations. This is especially likely to be true in the

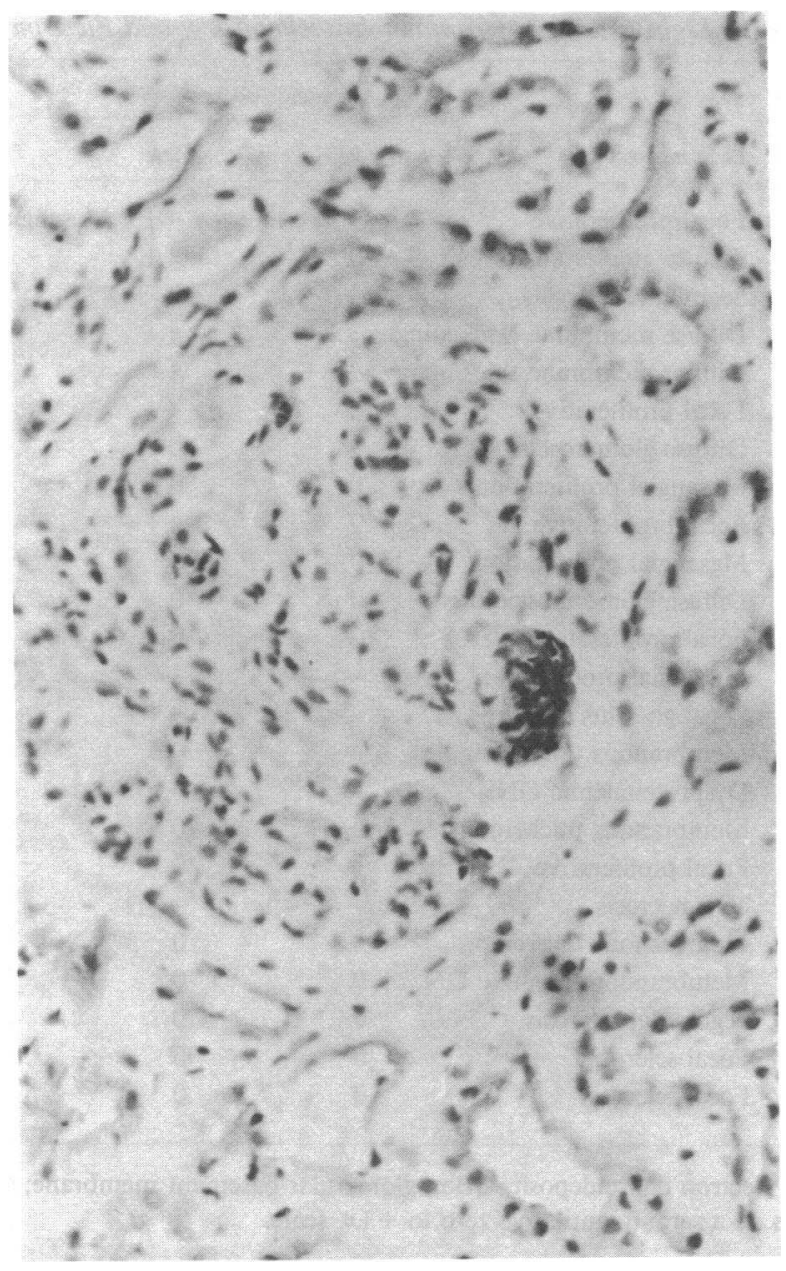

Figure 5. SLE patient 8. Focal proliferative lupus glomerulonephritis. Staining with anti-idiotype anti-sera (anti-16/6) shows positive staining of a discrete focal proliferative lesion. $\times 260$.

case of IgM antibodies, including the monoclonal anti-DNA antibodies described in this study, as these molecules are much less prone to undergo somatic change than IgG or IgA molecules (18). Thus, the sharing of idiotypes amongst autoantibodies may offer clues to their origins.

Earlier studies have demonstrated that there is much idiotype sharing amongst hybridoma-derived monoclonal antiDNA antibody molecules found in the New Zealand black mice/New Zealand white mice (NZB/NZW) $(19,20)$ and MRL lupus prone mice (21), and amongst human hybridomaderived anti-DNA autoantibodies (7). Further, anti-DNA autoantibody idiotype sharing has been shown amongst immunoglobulins in the serum of lupus patients (8). Although antiDNA antibodies detected in the serum of lupus patients may reflect disease activity, their potential contribution to the disease's immunopathology as part of immune complexes deposited within tissues is of greater importance.

Much interest has focused on the kidney damage in SLE patients, as renal disease remains the commonest cause of death in lupus (22). DNA antigens and/or antibodies have been detected in immune complexes in proliferative (23) and membranous lupus nephritis (24). Three immune complex systems have been recognized: dsDNA-anti-dsDNA, ssDNA- 
Table IV. Light Microscopy, Immunohistochemistry, and Electron Microscopy on the Disease Control Patients

\begin{tabular}{|c|c|c|c|c|c|c|c|}
\hline \multirow[b]{2}{*}{ Patient } & \multirow[b]{2}{*}{ Light microscopy } & \multicolumn{5}{|c|}{ Immunohistochemistry } & \multirow[b]{2}{*}{ Electron microscopy } \\
\hline & & IgG & IgA & IgM & $\mathrm{Clq}$ & C3 & \\
\hline A & Focal proliferative & + Mesangial & +++ Mesangial & 0 & 0 & ++ Mesangial & Mesangial and paramesangial EDD \\
\hline B & Diffuse glomerulosclerosis & 0 & ++ & 0 & 0 & 0 & GBm thickening. No EDD \\
\hline $\mathrm{C}$ & Segmental necrosis & + & 0 & 0 & 0 & + & No EDD \\
\hline D & Diffuse membrane thickening & +++ & ++ & 0 & +++ & +++ & Epimembranous EDD \\
\hline $\mathrm{E}$ & Diffuse membrane thickening & +++ & + & + & + & +++ & Epimembranous EDD \\
\hline $\mathrm{F}$ & Focal proliferative & 0 & ++ & + & + & 0 & Paramesangial and transmembranous \\
\hline G & Diffuse glomerosclerosis & + & 0 & 0 & 0 & 0 & GBm thickening \\
\hline $\mathbf{H}$ & Mesangial proliferation & 0 & 0 & ++ & + & ++ & No glomeruli \\
\hline I & Focal proliferative & 0 & +++ & 0 & 0 & ++ & Mesangial EDD \\
\hline $\mathbf{J}$ & Mesangial proliferation & 0 & 0 & + & + & 0 & No glomeruli \\
\hline $\mathrm{K}$ & Diffuse glomerulosclerosis & 0 & 0 & + & ++ & 0 & GBm thickening. Sclerosis \\
\hline $\mathrm{L}$ & Focal proliferative & 0 & 0 & + & ++ & 0 & No EDD. One glomerulus only \\
\hline $\mathbf{M}$ & Mesangial proliferation & - & - & - & - & - & No EDD \\
\hline $\mathbf{N}$ & Focal gn. plus crescents & - & +++ & ++ & - & +++ & Sclerosis with mesangial EDD \\
\hline $\mathrm{O}$ & Membranous thickening & +++ & ++ & + & ++ & +++ & Epimembranous EDD \\
\hline $\mathbf{P}$ & Dysproteinaemic GN & - & + & +++ & + & ++ & Subendothelial EDD \\
\hline Q & Membranous thickening & +++ & 0 & 0 & 0 & + & Epimembranous EDD \\
\hline $\mathbf{R}$ & Focal proliferative & + & 0 & + & 0 & + & Paramesangial EDD \\
\hline $\mathbf{S}$ & Tuft necrosis & - & - & - & - & - & Necrotic lesions \\
\hline $\mathrm{T}$ & Membranous thickening & ++ & 0 & + & 0 & 0 & Epimembranous EDD \\
\hline $\mathrm{U}$ & Membranoproliferative GN & 0 & 0 & 0 & 0 & + & Subendothelial EDD \\
\hline V & Segmental sclerosis & 0 & 0 & ++ & 0 & + & Sclerosis. No EDD \\
\hline W & Focal sclerosis & 0 & 0 & +++ & + & ++ & Sclerosis. Mesangial EDD \\
\hline $\mathrm{X}$ & Focal sclerosis & 0 & 0 & +++ & 0 & ++ & Sclerosis. Mesangial EDD \\
\hline
\end{tabular}

EDD, electron dense deposit; GBm, glomerular basement membrane; GN, glomerular nephritis. The scoring system for the immunohistochemistry is on a semi-quantitative zero to +++ scale.

anti-ssDNA, and ssDNA-anti-dsDNA (25). However, it is still not certain what determines the precise localization of immune complex deposition. It seems most probable that circulating immune complexes are trapped in the mesangial areas and subendothelial spaces of the glomerular capillary walls. However, subepithelial immune complexes are perhaps best explained by postulating that DNA might bind directly to the glomerular basement membrane and form immune complexes with circulating anti-DNA antibodies. Alternatively, the reaction might involve antibodies binding directly to renal glomerular antigens. These might include vimentin, a DNA-binding cytoskeletal protein $(26,27)$. Other factors relating to the pathogenicity of DNA antibodies include their complement-fixing ability, their avidity for DNA, and their antibody charge (28).

This study has shown that common, cross-reacting idiotypes

Table V. Blocking Studies with Anti-16/6R

\begin{tabular}{|c|c|c|c|c|c|}
\hline \multirow[b]{2}{*}{ Patient } & \multirow[b]{2}{*}{$\begin{array}{l}\text { Pre- } \\
\text { incubation } \\
\text { with PBS }\end{array}$} & \multicolumn{4}{|c|}{ Preincubation with: } \\
\hline & & $\begin{array}{l}2.5 \mu \mathrm{g} \\
\text { ssDNA }\end{array}$ & $\begin{array}{l}25 \mu \mathrm{g} \\
\text { ssDNA }\end{array}$ & $\begin{array}{l}2.5 \mu \mathrm{g} \\
\text { dsDNA }\end{array}$ & $\begin{array}{l}25 \mu \mathrm{g} \\
\mathrm{dsDNA}\end{array}$ \\
\hline 4 Mesangium & +++ & + & 0 & ++ & ++ \\
\hline \multirow{2}{*}{$\begin{array}{c}5 \text { Glomerular } \\
\text { basement } \\
\text { membrane }\end{array}$} & & & & & \\
\hline & +++ & +++ & ++ & + & + \\
\hline
\end{tabular}

are detectable on immunoglobulins found in the renal biopsies of patients with active lupus nephritis. These immunoglobulins may very well be concerned with immunopathology in SLE.

Table VI. Serum Levels of 16/6 and 32/15 Anti-DNA Antibody Idiotypes

\begin{tabular}{ccc} 
& \multicolumn{2}{c}{$\begin{array}{l}\text { Serum idiotype level optical } \\
\text { density units } \times 10^{3}\end{array}$} \\
\cline { 2 - 3 } Patient & $16 / 6$ & $32 / 15$ \\
\hline Idiotype-positive & & \\
1 & $370^{*}$ & $181^{*}$ \\
3 & 82 & 12 \\
8 & $381^{*}$ & 57 \\
9 & $621^{*}$ & $105^{*}$ \\
12 & $141^{*}$ & 16 \\
Idiotype-negative & & \\
14 & 89 & 9 \\
17 & 21 & 51 \\
19 & 12 & 29 \\
20 & 14 & 0 \\
23 & $341^{*}$ & $230^{*}$ \\
\hline
\end{tabular}

Upper limit of normal for $16 / 6=115 \mathrm{U}$; upper limit of normal for $32 / 15=85 \mathrm{U}$-these limits represent the mean $\pm 2 \mathrm{SD}$ of 115 healthy controls. For details of method see reference 8 .

* Raised level. 
With the limited amount of stored tissue available to us, we have not been in a position to determine if, in each case, the idiotypes we have detected are on DNA antibody molecules. However, in two $16 / 6$ idiotype-positive biopsies, successful blocking with ssDNA and dsDNA was achieved. This suggests that in these cases, the idiotypes are probably on anti-DNA antibodies.

It should be noted that although the $16 / 6$ and $32 / 15$ idiotypes were first identified on anti-DNA antibodies, they may not be confined to these molecules. Thus, in MRL-lpr/ lpr mice, most of the high frequency idiotype designated $\mathrm{H} 130$, although originally identified on anti-DNA antibodies, is present on other, unidentified, immunoglobulins (21). Idiotypes may be shared by antibody molecules with different antigen-binding properties $(29,30)$. Recently, A. Morgan and N. Staines (personal communication) have been unable to determine a relationship between the antigen binding and idiotypic patterns of a panel of monoclonal anti-DNA antibodies derived from NZB/NZBW $f_{1}$, and MRL-lpr mice. This would imply that idiotypes and antigen-binding sites (paratopes) of autoantibodies are encoded for by different subregions of $\mathrm{V}$ genes.

In 10 out of the 11 idiotype-positive biopsies in which they were tested for, IgM molecules were shown to be present by immunohistochemistry. The detection of idiotype-bearing molecules by the anti-idiotypic reagents on IgM molecules is probably explained by their pentameric structures. Thus, some free arms may simply have been available for binding to antiidiotypes. However, in one of the idiotype positive biopsies (patient 7), no IgM was detectable. Possible explanations are that a few IgM molecules were present, and the anti-idiotypic serum is simply more sensitive than routine immunohistochemistry; or the anti-idiotypes were binding to structures within the renal tissue that showed homology with their idiotypes. A further possibility, and one that applies to the other positive biopsies, is that the $16 / 6$ and 32/15 idiotypes are present on immunoglobulin molecules other than IgM. Support for this idea is suggested by the detection of the $16 / 6$ idiotype on affinity-purified IgG found in the serum of patients with benign (IgG) gammopathies (Shoenfeld, Y., and G. Lavi, personal communication). Finally, anti-DNA antibody antiidiotypes have been demonstrated in both normal (31) and lupus (32) serum. Thus, it could be postulated that at least some of the immune complexes present in the lupus kidney are not DNA and anti-DNA antibodies, but DNA antibody idiotypes complexed with anti-DNA antibody anti-idiotypes.

We have not had the opportunity to study unfixed (fresh frozen) sections of lupus kidney biopsies. However, it is noteworthy that using anti-16/6/R in a similar study of tissuebound immunoglobulins at the dermal-epidermal junction of skin biopsies (unfixed) from 24 SLE patients, $46 \%$ were positive. $^{2}$ This is strikingly similar to the $42 \%$ of the renal biopsies positive for $16 / 6$ in this study, and implies that sections are unlikely to be falsely negative due to problems of tissue fixation.

The detection of $16 / 6$ or $32 / 15$ in the serum of four out of five idiotype-positive biopsies was of interest; especially as they could be detected in the serum of only one out of five patients with idiotype-negative biopsies. However, the precise

2. Isenberg, Dudeney, Wojnaruska, Bhogal, Rauch, Schattner, Naparstek, Duggan, submitted for publications. relationship between serum idiotype levels and their detection in renal biopsies must await prospective studies.

This demonstration of cross-reactive idiotypes on tissuebound immunoglobulins must lead to further speculation about the potential therapeutic role of anti-idiotypes. There can be no doubt that whilst steroids and other immunosuppressives are a great improvement on earlier therapies for lupus, they lack the specificity of an ideal treatment and are very prone to cause side effects. Hahn and Ebling (33) have shown a significant (albeit limited) improvement in nephritis and survival in NZB/NZW $f_{1}$ mice treated with suitably timed injections of an anti-idiotypic reagent to anti-DNA antibodies. A single anti-idiotypic reagent, however, is unlikely to provide the complete answer as Hahn and Ebling (33) acknowledged, and there may even be a danger of augmenting the production of undesirable autoantibodies as Teitelbaum et al. have shown (34).

\section{Acknowledgments}

The authors gratefully acknowledge the encouragement and constructive criticism of Professors R. S. Schwartz and Isaacson. We also thank Dr. M. L. Snaith and Dr. S. L. Cohen for permission to study their patients. We gratefully acknowledge the excellent work done by $\mathrm{Mr}$. K. Miller.

\section{References}

1. Reichlin, M. 1983. Diagnosis, criteria and serology. In Clinical Management of Systemic Lupus Erythematosus. P. Schur, editor. Grune and Stratton, New York. 49-62.

2. Brentjens, J., E. Ossis, B. Albini, M. Sepulveda, K. Kano, J. Sheffer, P. Vasilon, E. Marine, T. Baliah, H. Jockin, and G. Andres. 1977. Dessiminated immune deposits in lupus erythematosus. Arthritis Rheum. 20:962-968.

3. Landry, P. H., and W. M. Sam. 1973. Systemic lupus erythematosus: studies of antibodies bound to skin. J. Clin. Invest. 52:18711880.

4. Richardson, B., and J. D. Stobo. 1981. Self recognition in the regulation of immune reactivity. Bull. Rheum. Dis. 31:26-30.

5. Schwartz, R. S. 1983. Monoclonal lupus autoantibodies. Immunol. Today. 4:68-9.

6. Solomon, G., J. Schiffenbauer, H. D. Kesser, and B. Diamond. 1983. Use of monoclonal antibodies to identify shared idiotypes on human antibodies to native DNA from patients with SLE. Proc. Natl. Acad. Sci. USA. 80:850-854.

7. Shoenfeld, Y., D. A. Isenberg, J. Rauch, M. P. Madaio, B. D. Stollar, and R. S. Schwartz. 1983. Idiotypic cross-reactions of monoclonal human lupus autoantibodies. J. Exp. Med. 158:718-730.

8. Isenberg, D. A., Y. Shoenfeld, M. P. Madaio, J. Rauch, M. Reichlin, B. D. Stollar, and R. S. Schwartz. 1984. Anti-DNA antibody idiotypes in SLE. Lancet. II:417-422.

9. Tan, E. M., A. S. Cohen, J. F. Fries, A. T. Masi, D. J. McShane, N. F. Rothfield, J. G. Schaller, N. Talal, and R. J. Winchester. 1982. The 1982 revised criteria for the classification of systemic lupus erythematosus. Arthritis Rheum. 25:1271-1277.

10. Mancini, G., A. O. Carbonara, and J. F. Heremans. 1965. Immunochemical quantification of antigens by single radial immunodiffusion. Immunochemistry. 2:235-254.

11. Morrow, W. J. M., D. A. Isenberg, A. Todd-Pokropek, H. F. Parry, and M. L. Snaith. 1982. Useful laboratory measurements in the management of systemic lupus erythematosus. Q. J. Med. NS. 52:125138.

12. Shoenfeld, Y., J. Rauch, H. Massicotte, S. K. Datta, J. André- 
Schwartz, B. D. Stollar, and R. S. Schwartz. 1983. Polyspecificity of monoclonal autoantibodies produced by human-human hybridomas. N. Engl. J. Med. 308:414-420.

13. Schreiber, R. D., and M. Reichlin. 1974. The occurrence of shared idiotypic specificity among goat antibodies that distinguish human haemoglobin S from A. J. Immunol. 113:359-366.

14. Kennedy, R. C., and G. R. Dreesman. 1983. Common idiotypic determinant associated with human antibodies to hepatitis $B$ surface antigen. J. Immunol. 130:385-389.

15. Kunkel, H. G., V. Agnello, F. G. Joslin, R. J. Winchester, and J. D. Capra. 1973. Cross-idiotypic specificity among monoclonal IgM proteins with anti- $\gamma$ globulin activity. J. Exp. Med. 137:331-342.

16. Lefvert, A. K. 1981. Anti-idiotypic antibodies against the receptor antibodies in myasthenia gravis. Eur. J. Immunol. 13:493497.

17. Matsuyama, T., J. Fukumori, and H. Tanaka. 1983. Evidence of unique idiotypic determinants and similar idiotypic determinants on human anti-thyroglobulin antibodies. Clin. Exp. Immunol. 51:381386

18. Gearhart, P. J. 1982. Generation of immunoglobulin variable gene diversity. Immunol. Today. 3:107-112.

19. Tron, F., C. Guern, R. A. Cazenares, and J. F. Bach. 1982. Intrastrain recurrent idiotypes among anti-DNA antibodies (NZB $\times$ NZW) F1 hybrid mice. Eur. J. Immunol. 12:761-766.

20. Marion, T. N., A. R. Lawton, J. F. Kearney, and D. E. Briles. 1982. Anti-DNA autoantibodies in (NZB $\times$ NZW) F1 mice are clonally heterogeneous, but the majority share a common idiotype. J. Immunol. 128:668-674.

21. Rauch, J., E. Murphy, J. B. Roth, B. D. Stollar, and R. S. Schwartz. 1982. A high frequency idiotype marker of anti-DNA autoantibodies is MRL/lpr/lpr mice. J. Immunol. 129:236-241.

22. Rosner, S., E. M. Ginzler, H. S. Diamond, M. Weiner, M. Schlesinger, J. F. Fries, C. Warner, T. A. Medsger, G. Ziegler, J. H. Klippel, N. M. Hadler, D. A. Albert, E. V. Hess, G. Spencer-Green, A. Grayzel, D. Worth, B. H. Hahn, and E. V. Barnett. 1982. A multicenter study of outcome in systemic lupus erythematosus II. Causes of death. Arthritis Rheum. 25:612-617.
23. Agello, V. 1976. Immunopathogenesis of lupus nephritis. Adv. Nephrol. 6:119-136.

24. Andres, G., L. Accinni, S. Beiser, C. L. Christian, G. A. Cinotti, B. F. Erlanger, K. C. Hsu, and B. C. Seegal. 1970. Localization of fluorescein-labeled anti-nucleoside antibodies in glomeruli of patients with active systemic lupus erythematosus nephritis. J. Clin. Invest. 49: 2106-2108.

25. Brentjens, J. R., and G. A. Andres. 1982. The pathogenesis of extra-renal lesions in systemic lupus erythematosus. Arthritis Rheum. 25:880-886.

26. Traub, P., W. J. Nelson, S. Kühn, and C. E. Vorgias. 1983. The interaction in vitro of the intermediate filament vimentin with naturally occurring RNAs and DNAs. J. Biol. Chem. 258:1456-1466.

27. André-Schwartz, J., S. K. Datta, Y. Shoenfeld, D. A. Isenberg, B. D. Stollar, and R. S. Schwartz. 1984. Binding of cytoskeletal proteins by monoclonal anti-DNA lupus autoantibodies. J. Immunol. Immunopathol. 31:261-271.

28. Hahn, B. 1982. Characteristics of pathogenic subpopulations of antibodies to DNA. Arthritis Rheum. 25:747-752.

29. Karol, R., M. Reichlin, and R. W. Noble. 1978. Idiotypic cross-reaction between antibodies of different specificities. J. Exp. Med. 148:1488-1497.

30. Hiernaux, J., and C. A. Bona. 1982. Shared idiotypes among monoclonal antibodies specific for different immunodominant sugars of lipopolysaccharide of different gram negative bacteria. Proc. Natl. Acad. Sci. USA. 79:1616-1620.

31. Zouali, M., and A. Eyquem. 1983. Expression of anti-idiotypic clones against auto anti-DNA antibodies in normal individuals. Cell Immunol. 176:137-147.

32. Zouali, M., and A. Eyquem. 1983. Idiotypic anti-idiotypic interactions in SLE. Ann. Immunol. 134C:377-397.

33. Hahn, B. H., and F. M. Ebling. 1984. Suppression of murine lupus nephritis by administration of an anti-idiotypic antibody to antiDNA. J. Immunol. 132:187-190.

34. Teitelbaum, D., J. Rauch, B. D. Stollar, and R. S. Schwartz. 1984. In vivo effects of antibodies against a high frequency idiotype of anti-DNA antibodies in MRL mice. J. Immunol. 132:1282-1285. 